\title{
Leadership As Service: A New Model for Higher Education in a New Century
}

\author{
By Kent A. Farnsworth, American Council on Education, \\ Praegar, 2007; ISBN: 0-275-99092-3; 176pp; US\$44.95
}

International Journal of Educational Advancement (2007) 7, 349-351. doi:10.1057/palgrave.ijea.2150077

In a new book confronting traditional models of leadership in higher education, Kent A. Fransworth observes, "We have created a synthetic society that we refer to as collegial, but which is essentially a power-over system in which we compare ourselves to each other on a 'greater than' or 'less than' scale-the antithesis of a service-centered culture." Both conceptual and practical, he offers leadership insights, based on the writings of Robert Greenleaf (1977) and Mary Parker Follett (1920, 1924), for college and university faculty and chief administrators, attempting to create a sense of urgency for responding to societal and global needs. Farnsworth pictures postsecondary institutions as a societal "subsystem" that is guilty of neglect and needs to question traditional definitions and roles. He unfolds a "new" model for higher education, as firmly established in the ancient wisdom traditions. His aim is "to lead a conversation, share ideas, point to successes" through case studies and personal experience as a faculty member and a chief administrator. This is a book of, at times, unrelated insights, lacking a clear normative framework, in which the author attempts to explain "syncretic leadership" as service and concludes with five transformationsthrough technology, information expansion, geopolitical, ecological, and social transformation-as a part of a collective vision for education for a new century.

Structurally, this book is written more as a series of essays on similar topics and less as a cohesive and linear research-oriented work. Farnsworth is at his best when he applies practical wisdom to critical issues that administrative leaders face, such as leading a university through major change and restructuring curriculum. He offers a "spiritual" approach to leadership-the return to the meaning of work-one that involves hearing differing voices and intrinsic needs of their colleagues. His charge is to renew the teaching and learning function of higher education with an outward orientation to economic development, revitalizing the job market and engaging global needs. 
Farnsworth reiterates several emphases, or themes, that are worth mention and analysis. The first, which has been noted, is the theme of the institution as public and global servant. He cites the need for universities to break from the old "feudal system" and concern themselves with the market. Richardson et al. (1998) suggest that change is implicit when institutional behavior becomes more sensitive to market forces such as student demand and economic development. Farnsworth warns that executives are beginning to conceptualize the CEO of a business as dean of a college, thus redefining what formal education means. Institutions, as Farnsworth sees them, are congruent with a "contingency theory" lens in which a rapidly changing environment requires an organic structure characterized by flexibility, adaptation, and effective communication (Gumport and Sporn, 1985). The world has now become a global village-facing institutions with issues of poverty, equity, and access.

Yet Farnsworth is silent of the issue of how far institutions should allow market forces to impinge upon their priorities. Along with market approaches come the view that academe is a business. Kezar (2004) points out that in "neoliberal logic, college and university students are seen as human capitol...they are 'customers' and education is a 'product.'" Higher education has in its purpose the formation of and development of informed citizens, whereas a business model is concerned with a measurable bottom line. Tierney (1999) likens the university to something more like a religion than a business. The fallacy in applying business models to a loosely coupled organization is that the structure will not support it. There has been a common trend of "management fads" such as Total Quality

Management (TQM) - as Farnsworth mentions-being adopted, evolving and phasing out before the culture is affected in any lasting way (Birnbaum, 2000).

"Syncretic" leadership through divergence, criticism, and dialogue are another major emphasis. Follett's "Law of the Situation" suggests that university leaders must be approachable, vulnerable to criticism and good listeners using a process of consensus to arrive at decisions. Fransworth's often inspirational and inclusive model diverges with research that suggests faculty participation and performance in general administrative and financial decisions can be counterproductive in an institution (Brown, n.d.). A criticism in using a syncretic approach to wisdom traditions and religions is that it theoretically contradicts the leadership style espoused. Throughout this work he uses the examples of Gandhi, Martin Luther King, Jr., and John Woolman in connection with service as leadership, yet these men did not themselves practice a syncretic approach. They were all deeply rooted in a religious tradition. Syncretism superficially denies difference and undermines the applicability of Follett's "Law of the Situation."

Farnsworth advocates power being shared more widely across the institution. Hierarchy, status, rank, and bureaucracy constitute the old paradigm and power should be realized as collective and shared between faculty, administrators, and students. Research on interactions with 
this structure reveal that bureaucratic operations largely go unchallenged (Godwin and Markham, 1996). Higher education should welcome such challenges to this outmoded model. In this same vein, one might imagine Farnsworth as opposing tenure. Yet, surprisingly he supports tenured faculty as social critics, which seems incommensurate with advocating a "power-with" scheme because of the long history of prestige and status associated.

Finally, at the core of proposed reform is a revitalization and reprioritization of excellence in teaching and learning within the academy. Farnsworth points to his mentor, Charles McClain, former President of Truman State University, who led faculty to transform the quality of his institution. He clearly and eloquently examines what a diverse committee must agree on to rejuvenate their educational missions. However, one cannot afford to be syncretic about the diversity and complexity of university missions. One must be cautious about universal application and acknowledge that Farnsworth's perspective aligns more with the community college mission. Future research in "leadership as service" models should explore and not equivocate various institutional structures and missions.
Joshua M. Hayden Vanderbilt University, USA

\section{References}

Birnbaum, R. (2000), "The life cycle of academic management fads," The Journal of Higher Education, 71, 1, pp. 1-16.

Brown, W.O. (n.d.), "Faculty participation in university governance and the effects on university performance," Claremont Colleges Working Papers in Economics, pp. 18+.

Follett, M.P. (1920), The New State, Longmans, Green and Co., New York.

Follett, M.P. (1924), Creative experience, Longmans, Green and Co., New York.

Godwin, G.J. and Markham, W.T. (1996), "First encounters of the bureaucratic kind: Early freshman experiences with a campus bureaucracy," Journal of Higher Education, 67, 6, pp. 660-691.

Greenleaf, R. (1977), Servant Leadership: A Journey Into The Nature of Legitimate Power and Greatness, Paulist Press, New York.

Gumport, P.J. and Sporn, B. (1985), "Institutional adaptation: Demands for management reform and university administration," in J. Smart and W.G. Tierney (eds.), Higher Education Handbook of Theory and Research, Vol. XIV, Agathon Press, New York, pp. 103-145.

Kezar, A. (2004), “Obtaining integrity?: Reviewing and examining the charter between higher education and society," The Review of Higher Education, 27, 4, pp. 429-459.

Richardson, R.C., Bracco, K.R., Callan, P.M. and Finney, J.E. (November 1998), "Higher education governance: Balancing institutional and market influences," The National Center for Public Policy and Higher Education, Vol. 98-7, pp. iii-27.

Tierney, W.G. (1999), Building Responsive Campus: Creating High Performance Colleges and Universities, Sage Publications, London, pp. 121-151. 